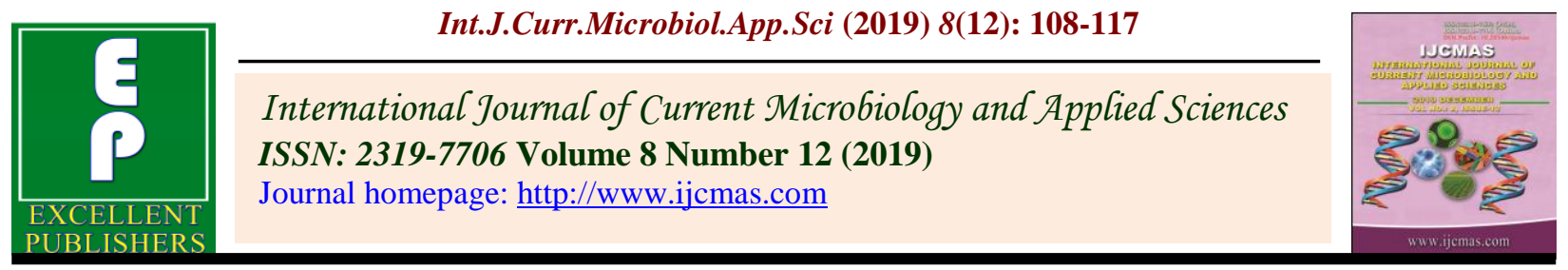

Original Research Article

https://doi.org/10.20546/ijcmas.2019.812.017

\title{
Influence of PGRs and Poultry Manure on Physico-Chemical Parameters of Strawberry (Fragaria $x$ ananassa Duch.) cv. Chandler
}

\author{
Sevan Das Khunte*, Anil Kumar, Naiem Ansari and S. Saravanan \\ Department of Horticulture, Allahabad School of Agriculture, Sam Higginbottom Institute of \\ Agriculture, Technology and Sciences (Deemed to-be University), \\ Allahabad-211007 (U.P.), India \\ *Corresponding author
}

Keywords

Cycocel (CCC),

GA3, NAA, Poultry

Manure (OM) and

Triacontanol

Article Info

Accepted:

04 November 2019

Available Online:

10 December 2019

\section{A B S T R A C T}

A field experiment was conducted during the winter season at the experimental field of the Department of Horticulture, Allahabad School of Agriculture, SHIATS, Allahabad (U.P.) entitled "Influence of PGRs and Poultry Manure on physico-chemical parameters of Strawberry (Fragaria $x$ ananassaDuch.) $c v$. Chandler." PGRs namely NAA (100, 150 and 200 ppm), $\mathrm{GA}_{3}(100,150$ and $200 \mathrm{ppm})$, Triacontanol (100, 150 and $\left.200 \mathrm{ppm}\right)$ and CCC (400, 800 and $1200 \mathrm{ppm})$ were applied as foliar spray and poultry manure $\left(2.50,5.50\right.$ and 8.50 tones $\left.\mathrm{ha}^{-1}\right)$ was mixed in soil during field preparation. The results revealed that treatment $\mathrm{T}_{3}$ showed the maximum fruit weight $(16.84 \mathrm{~g})$, fruit length diameter ratio (1.58) and specific gravity (1.34). Maximum $\mathrm{p}^{\mathrm{H}}$ value (3.90) and total soluble solid (10.19 $\mathrm{brix}$ ) were reported with the treatment $\mathrm{T}_{12}$. The maximum juice content $(90.12 \%)$ of fruit was recorded with treatment $\mathrm{T}_{10}$. However the maximum acidity of fruit juice $(0.87 \%)$ was observed under treatment $\mathrm{T}_{9}$.

\section{Introduction}

The common cultivated strawberry (Fragaria $x$ ananassa Duch.) is considered as a man made hybrid crop evolved by crossing between $F$. virginiana and $F$. chilonensis. $F$. species and belongs to rosaceae family with basic chromosome number $X=7$. Genus Fragaria includes atleast 17 other species (diploid, tetraploid, hexaploid and octoploid). The cultivated strawberry is an octoploid $(2 n=8 x=56)$. Strawberry is the most delicious and refreshing soft fruits of the world. It is an aggregate fruit and non-climateric fruit which develops by simultaneous ripening of the number of separate berries of a single flower (Fig. 3), adhering as the common unit on the common receptacle, botanically called as 
"etaerio of achenes". Strawberry can be grown in wide climatic conditions, ranging from temperate to tropical climate.

Growth and development of strawberry is highly sensitive to variations in air and soil temperature. An optimum growing season temperature of $15^{\circ} \mathrm{C}$ has been reported for most of the strawberry cultivars and species have found range between 20 to $26^{\circ} \mathrm{C}$, the ambient temperature for proper growth (Larson et al., 1994). Organic manures in soil have been associated with increases in waterholding capacity, cation-exchange capacity, aeration and root depth as well as decrease in soil crusting and erosion. Continuous and indiscriminate use of chemical fertilizers has caused serious damage to the soil ecosystem and physico-chemical characteristics so there is need to use the organic manure in place chemical fertilizers to maintain the soil ecosystem. Organic manures in soil have been associated with increases in water-holding capacity, cation-exchange capacity, aeration and root depth as well as decrease in soil crusting, erosion and maintain the soil ecosystem. Vegetative growth of plant was increased by organic manures treated strawberry (Ngodup and Saravanan, 2010).

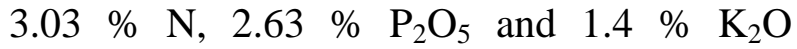
nutrient composition of poultry manures (Katyayan, 2008). Poultry manure was fruit yield increased with 50\% NPK combination and ascorbic acid also increased (Subhjith and Prasad, 2010).

The fruit quality is very good in hills as compared to plains. Similarly, the colour and flavor development is not proper in plains. Strawberry consumption can reduce the risk of cancer by $50 \%$ due to high level of vitamin - C (30 - $100 \mathrm{mg} / 100 \mathrm{~g})$ foliate and photochemical compound such as the ellagic acid present in the fruit. Plant growth retardants generally have great effects on cells elongation, where inhibition of $\mathrm{GA}_{3}$ synthesis rapidly causes reduction in stem elongation and leaf expansion (Tanimoto, 1983). $\mathrm{GA}_{3}$ at $100 \mathrm{ppm}$ concentration produced tallest plants (20.39 $\mathrm{cm})$ with higher number of leaves (18.09) and number of flowers (16.23). Further this treatment extended the duration of flowering (72.66 days) and resulted in higher yield (112.95 g.) per plant with maximum length $(3.09 \mathrm{~cm})$ and weight $(8.02 \mathrm{~g}$.) of berries. The maximum berry breadth $1.93 \mathrm{~cm}$ was recorded in strawberry plants with CCC at $1000 \mathrm{ppm}$ followed by $\mathrm{GA}_{3}$ at $100 \mathrm{ppm}(1.91 \mathrm{~cm})$ (Tripathi and Shukla, 2006). Triacontanol treated plants increased number of root which causes plants to take up more nutrients from soil and increased production per plants (Blarke and Lenz, 1983). The highest number of fruits (23.31), yield per hectare (27.90 tones), length diameter (1.50) and $\mathrm{B}$ : $\mathrm{C}$ ratio was recorded with triacontanol treated strawberry (Kumar et al., 2011). The highest grass return, net return and $\mathrm{B}$ : $\mathrm{C}$ ratio was recorded with CCC treated strawberry (Kumar et al., 2012). The highest number of leaves per plant and leaf area was found with triacontanol and anthocyanin content was increased with CCC treated plant (Thakur et al., 1991) .The highest fruit diameter, weight, volume, acidity per cent (as citric acid equivalent) and the lowest sugar: acid ratio with 400 ppm NAA treated strawberry plant (Techawongstein, 1989).

\section{Materials and Methods}

The present investigation was carried out under Allahabad agro-climatic conditions at the experimental field of the Department of Horticulture, Allahabad School of Agriculture, Sam Higginbottom Institute of Agriculture, Technology and Sciences, Deemed to-be University, Allahabad U.P. (Fig. 1)

The soil ploughed 2-4 times by cultivator, harrowed, leveled and the weeds were rooted out from experimental field. Runners of 
strawberry cv. Chandler transplanted in uniform plots during evening with $45 \mathrm{~cm} \mathrm{x}$ $30 \mathrm{~cm}$ planting spacing. Thirteenth treatment combinations were randomized in three replications.

The various combination of poultry manure (tone/ha) and different Plant growth regulators were as: $\mathrm{T}_{1}-$ (control), $\mathrm{T}_{2}-$ (Poultry Manure 2.50 tonnes + NAA $100 \mathrm{ppm}), \mathrm{T}_{3}$-(Poultry Manure 2.50 tonnes + Triacontanol $100 \mathrm{ppm})$, $\mathrm{T}_{4}-$ (Poultry Manure 2.50 tonnes + Cycocel $400 \mathrm{ppm}), \mathrm{T}_{5}-$ (Poultry Manure 2.50 tonnes + $\mathrm{GA}_{3} 100 \mathrm{ppm}$ ), $\mathrm{T}_{6}$-(Poultry Manure 5.50 tonnes + NAA $150 \mathrm{ppm}), \mathrm{T}_{7}-($ Poultry Manure 5.50 tonnes + Triacontanol $150 \mathrm{ppm}), \mathrm{T}_{8}$ (Poultry Manure 5.50 tonnes + Cycocel 800 ppm), $\mathrm{T}_{9}-$ (Poultry Manure 5.50 tonnes $+\mathrm{GA}_{3}$ $150 \mathrm{ppm}$ ), $\mathrm{T}_{10}-$ (Poultry Manure 8.50 tonnes + NAA200 ppm) $\mathrm{T}_{11}-$ (Poultry Manure 8.50 tonnes + Triancontanol200 $\mathrm{ppm}), \mathrm{T}_{12}-$ (Poultry Manure 8.50 tonnes + CCC1200 ppm) and $\mathrm{T}_{13}-$ (Poultry Manure 8.50 tonnes + $\mathrm{GA}_{3} 200$ ppm) (Fig. 3).

Poultry manure broadcasted according to various treatment combinations during layout of experimental plots twenty days before transplanting. $\mathrm{GA}_{3}$ and triacontanol dissolve powder in a small volume of alcohol. 5-10 ml. Alcohol solvents listed above.

$\mathrm{GA}_{3}$ solution was slight heated to improve solubility. Measure $1000 \mathrm{ml}$ (1.0 litre) of good quality water and was added liquid hand dish washing soap at 1-5 drops. It was best to shake before each spraying.

Aim for coating the upper surface of the plant leaves thoroughly, Spay enough to allow drip down from the leaves, stems and shoots also. The observations were recorded on Qualitative characters in terms length diameter ratio, Fruit weight (fruit/g), specific gravity, $\mathrm{pH}$ of fruit juice, acidity of fruit juice, ascorbic acid, juice content of fruit, TSS of fruit (Fig. 2).

\section{Results and Discussion}

The various treatments showed significant effect on length diameter ratio of fruits. The maximum length diameter ratio of fruit (1.58) was observed with treatment $T_{3}$. The minimum length diameter ratio of fruit (1.36) was observed with treatment $T_{1}$. These results were in close conformity with the findings of Kumar et al., (2011). The maximum weight of each fruit (16.84 g) was observed with treatment $\mathrm{T}_{3}$ (2.50 tones poultry manure +100 ppm triacontanol) followed by (16.46 g) with treatment $\mathrm{T}_{7}(5.50$ tones poultry manure +150 ppm triacontanol).

The maximum specific gravity (1.34) was observed with treatment $\mathrm{T}_{3}$. The minimum specific gravity (1.14) was recorded in treatment $\mathrm{T}_{5}$. Similar results were also reported by Kumar et al., (2011). The present data shown in table 1 and it was found that effect of plant growth regulators and organic manure on $\mathrm{pH}$ of the fruit juice was significant. The maximum $\mathrm{pH}$ of the fruit juice (3.90) was observed with treatment $\mathrm{T}_{12}$ followed by treatment $\mathrm{T}_{4}$. The minimum $\mathrm{pH}$ of the fruit juice (3.34) was observed with treatment $T_{3}$. These results were in close conformity with the findings of Kumar et al., (2011). The maximum acidity of fruit juice $(0.87 \%)$ was observed with treatment $\mathrm{T}_{9}$. The minimum acidity of fruit juice $(0.74 \%)$ was observed with treatment $\mathrm{T}_{5}$. Similar findings were also reported by Singh and Singh (1979) and Kumar et al., (2012). The various treatments showed significant effect on ascorbic acid of fruits. The maximum ascorbic acid $(58.71 \mathrm{mg} / 100 \mathrm{~g}$ pulp) was observed with treatment $\mathrm{T}_{4}$. The minimum ascorbic acid of fruit $(50.51 \mathrm{mg})$ was observed under treatment $\mathrm{T}_{1}$. Similar findings were also reported by Singh and Phogat, (1983). The maximum juice content of fruit $(90.12 \%)$ was observed with treatment $\mathrm{T}_{10}$. Similar finding were also reported by Kumar et at., (2012) (Fig. 4-10). 
Table.1 Influence of PGRs and Poultry Manure on physico-chemical parameters of Strawberry

\begin{tabular}{|c|c|c|c|c|c|c|c|c|c|c|c|}
\hline Treatment & $\begin{array}{c}\text { plant } \\
\text { height } \\
\text { (cm) }\end{array}$ & $\begin{array}{c}\text { Plant } \\
\text { Spread } \\
\text { (cm) }\end{array}$ & $\begin{array}{c}\text { Total no of } \\
\text { fruits per } \\
\text { plant }\end{array}$ & $\begin{array}{c}\text { Fruit yield } \\
\text { per plant } \\
\text { (g) }\end{array}$ & $\begin{array}{l}\text { Length : } \\
\text { diameter } \\
\text { ratio }(\mathrm{cm})\end{array}$ & $\begin{array}{l}\text { Specific } \\
\text { gravity }\end{array}$ & $\begin{array}{c}\mathrm{pH} \\
\text { value }\end{array}$ & $\begin{array}{c}\text { Acidity } \\
(\%)\end{array}$ & $\begin{array}{c}\text { TSS } \\
\left({ }^{\mathbf{0}} \text { Brix }\right)\end{array}$ & $\begin{array}{c}\text { ascorbic } \\
\text { acid } \\
(\mathrm{mg} / 100 \mathrm{~g})\end{array}$ & $\begin{array}{c}\text { Juice } \\
\text { content } \\
(\%)\end{array}$ \\
\hline $\mathbf{T}_{1}$ & 13.08 & 20.25 & 11.47 & 146.80 & 1.36 & 1.16 & 3.37 & 0.77 & 8.26 & 50.51 & 84.20 \\
\hline $\mathbf{T}_{2}$ & 14.03 & 22.54 & 15.67 & 227.90 & 1.51 & 1.20 & 3.66 & 0.78 & 9.16 & 52.63 & 88.74 \\
\hline $\mathbf{T}_{3}$ & 14.05 & 21.51 & 17.93 & 301.94 & 1.58 & 1.34 & 3.34 & 0.79 & 9.21 & 54.07 & 85.70 \\
\hline $\mathbf{T}_{4}$ & 12.82 & 20.08 & 17.40 & 270.22 & 1.47 & 1.20 & 3.86 & 0.81 & 9.34 & 58.71 & 89.69 \\
\hline $\mathbf{T}_{5}$ & 21.35 & 23.85 & 15.27 & 207.43 & 1.43 & 1.14 & 3.68 & 0.74 & 8.92 & 54.79 & 85.56 \\
\hline $\mathbf{T}_{6}$ & 15.63 & 21.86 & 15.13 & 226.79 & 1.52 & 1.24 & 3.74 & 0.75 & 9.52 & 51.45 & 87.60 \\
\hline $\mathbf{T}_{7}$ & 16.03 & 23.89 & 20.07 & 330.18 & 1.56 & 1.30 & 3.79 & 0.83 & 8.76 & 53.81 & 87.22 \\
\hline $\mathbf{T}_{8}$ & 12.15 & 19.76 & 19.33 & 317.84 & 1.53 & 1.23 & 3.65 & 0.79 & 9.70 & 56.95 & 86.78 \\
\hline $\mathbf{T}_{9}$ & 24.41 & 24.81 & 14.47 & 181.22 & 1.40 & 1.18 & 3.45 & 0.87 & 9.52 & 55.13 & 86.33 \\
\hline $\mathbf{T}_{10}$ & 15.09 & 24.19 & 16.20 & 224.96 & 1.41 & 1.17 & 3.50 & 0.82 & 8.99 & 53.23 & 90.12 \\
\hline$T_{11}$ & 15.98 & 21.93 & 19.50 & 305.57 & 1.49 & 1.21 & 3.69 & 0.76 & 9.11 & 52.34 & 85.31 \\
\hline $\mathbf{T}_{12}$ & 11.31 & 19.37 & 18.20 & 293.07 & 1.46 & 1.22 & 3.90 & 0.75 & 10.19 & 57.33 & 88.10 \\
\hline $\mathbf{T}_{13}$ & 27.57 & 26.41 & 13.53 & 163.35 & 1.42 & 1.19 & 3.55 & 0.80 & 7.86 & 56.18 & 83.71 \\
\hline f-test & $S$ & $S$ & $\mathrm{~S}$ & $S$ & $\mathrm{~S}$ & $S$ & $\mathrm{~S}$ & NS & $S$ & $S$ & $\mathrm{~S}$ \\
\hline CD at 0.05 & 1.47 & 2.59 & 2.89 & 28.18 & 0.06 & 0.11 & 0.34 & 0.11 & 0.76 & 1.15 & 1.48 \\
\hline
\end{tabular}


Fig.1 Experimental plots

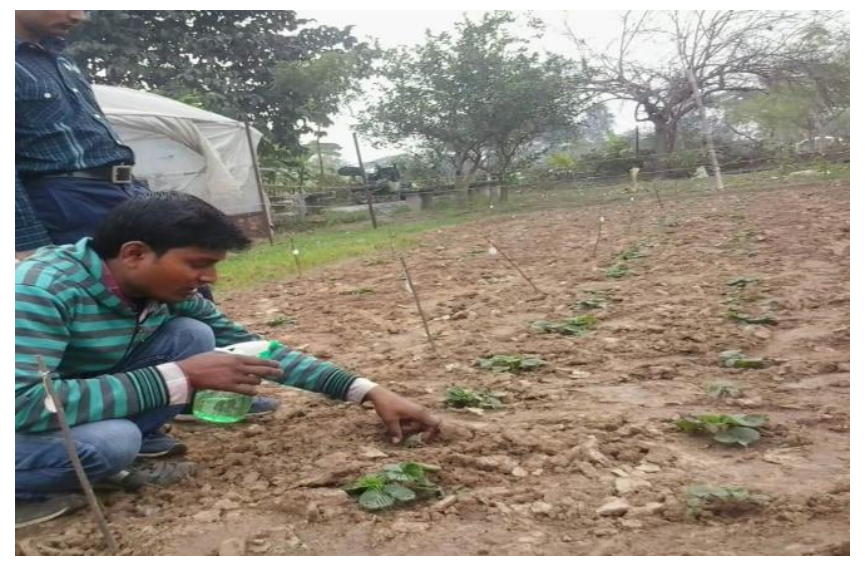

Fig.2 Harvested fruits from the experimental plots

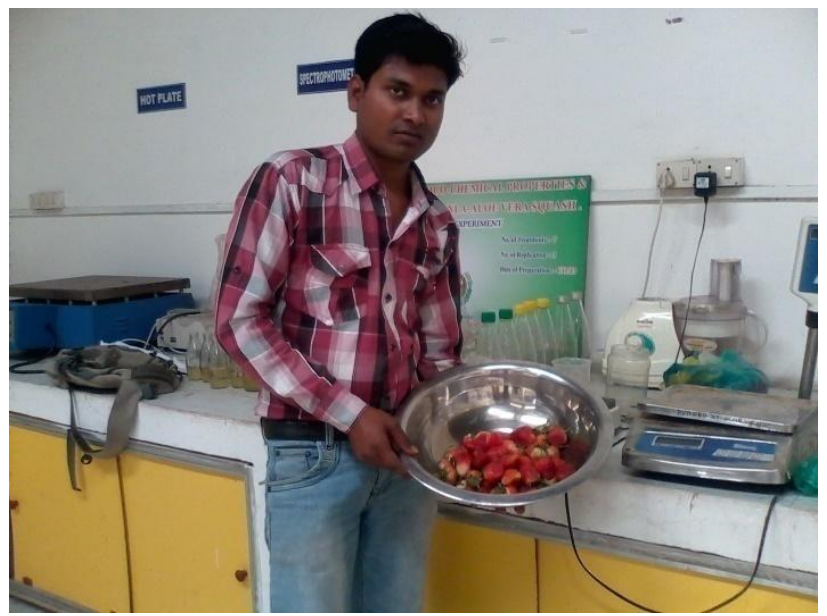

Fig.3 During ripening of fruits in plant

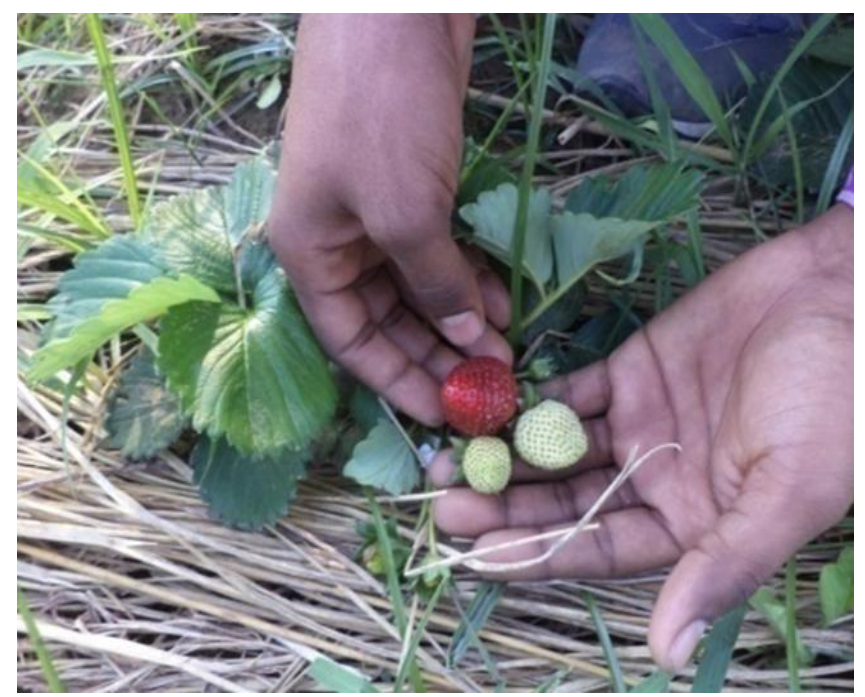


Fig.4 Influence of PGRs and poultry manure on length: diameter ratio of fruit of Strawberry

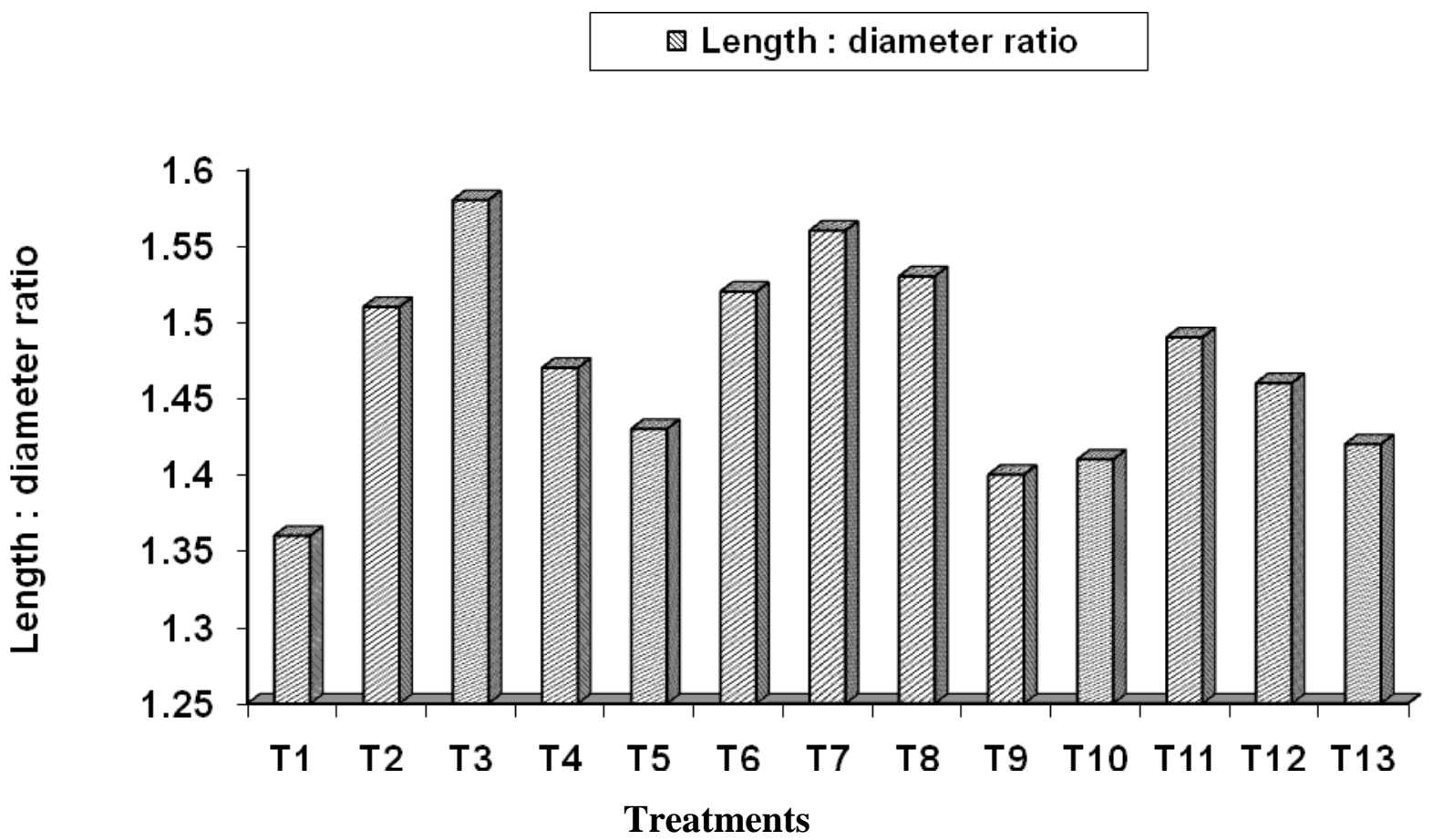

Fig.5 Influence of PGRs and poultry manure on specific gravity of fruit of Strawberry

$\mathbb{\Delta}$ Specific gravity

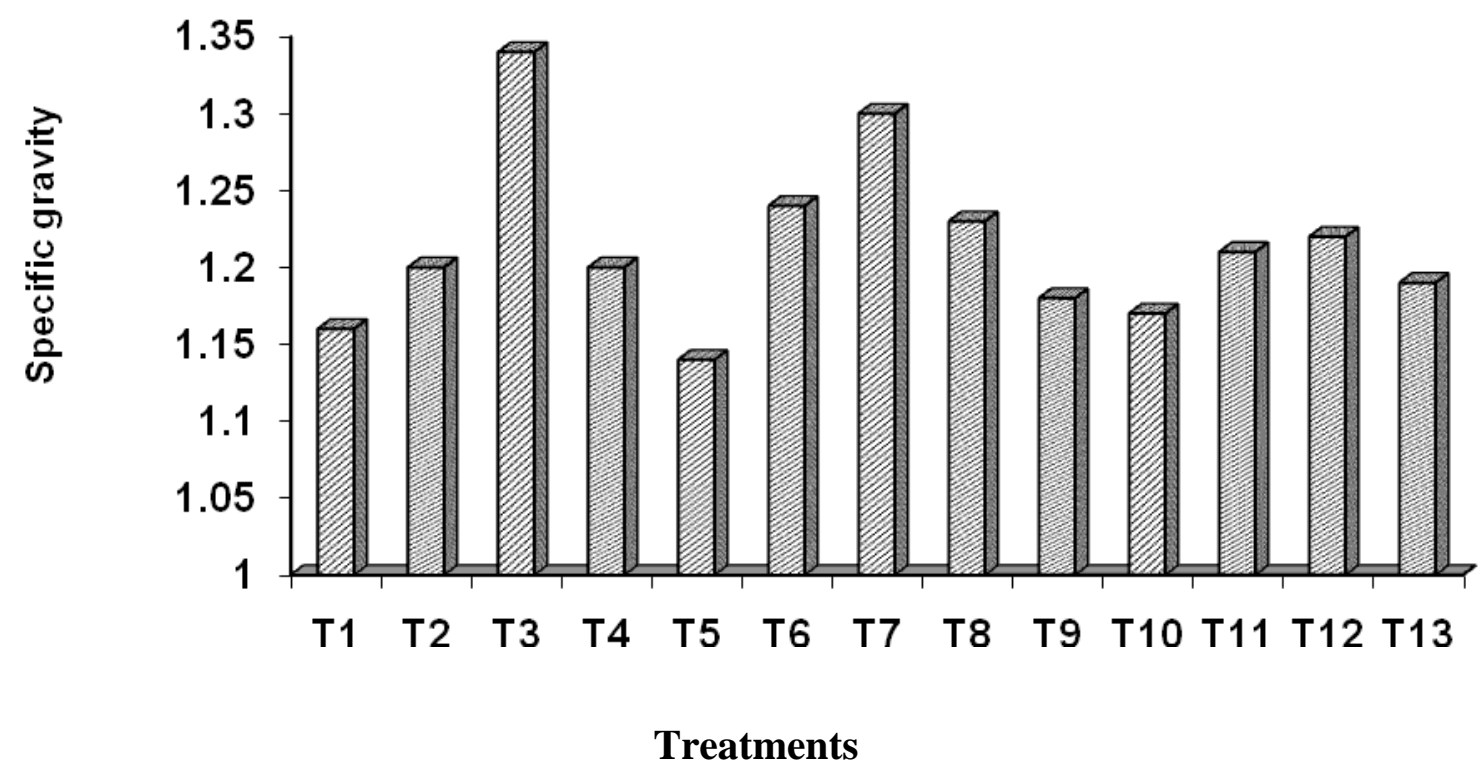


Fig.6 Influence of PGRs and poultry manure on $\mathrm{pH}$ of fruit juice of Strawberry

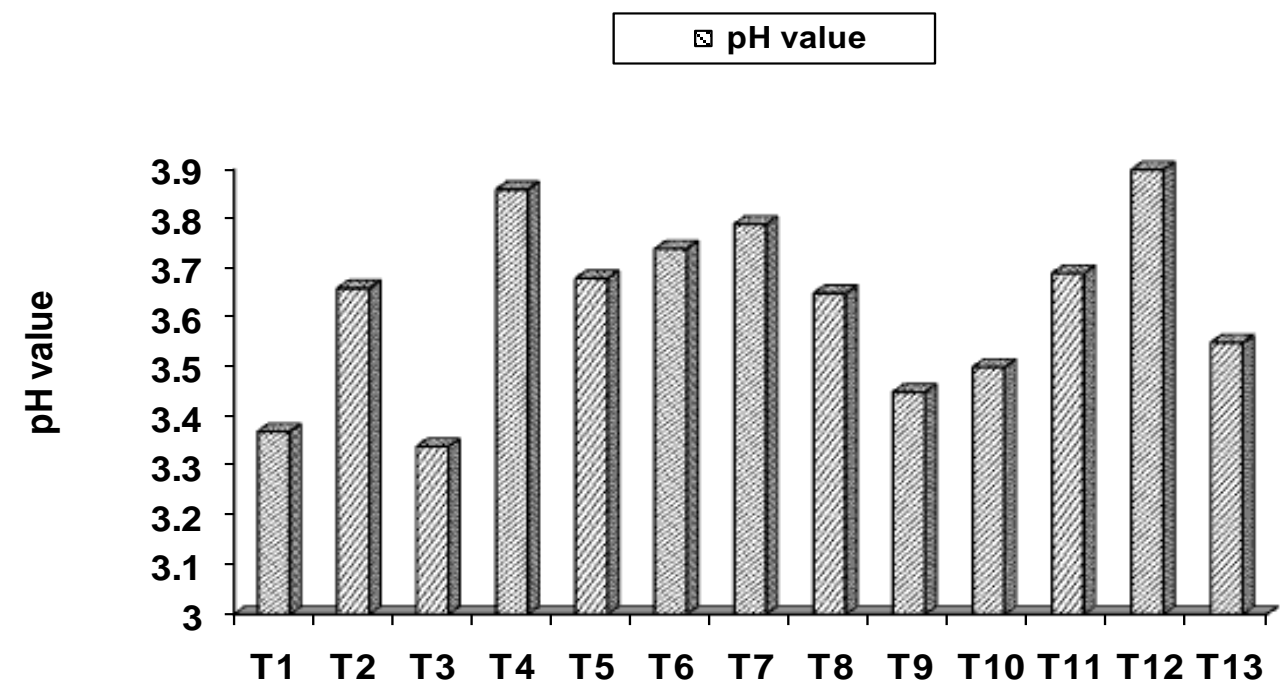

\section{Treatments}

Fig.7 Influence of PGRs and poultry manure on acidity of fruit juice (\%) of Strawberry

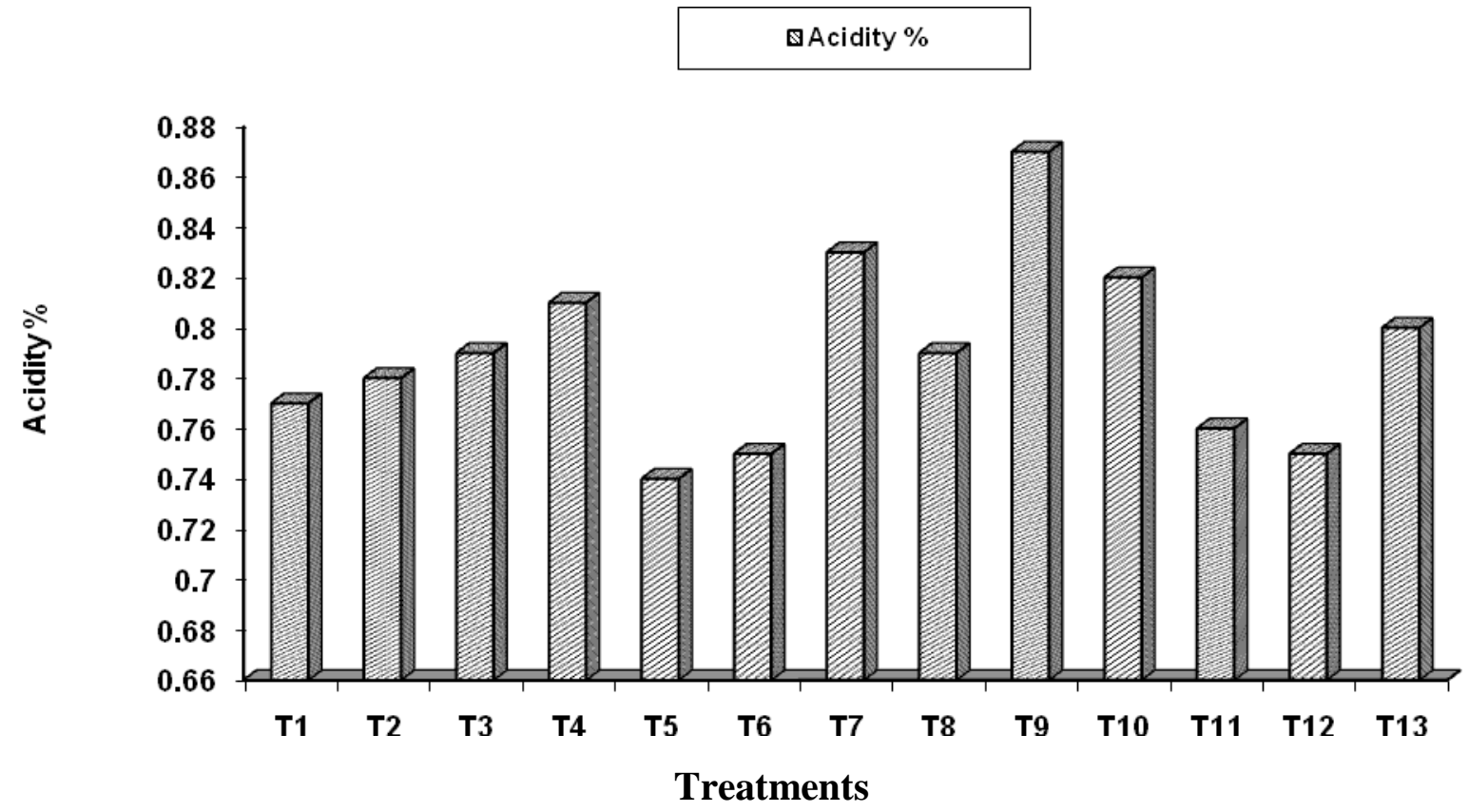


Fig.8 Influence of PGRs and poultry manure on total soluble solids ( $\left({ }^{\circ} \mathrm{Brix}\right)$ of Strawberry

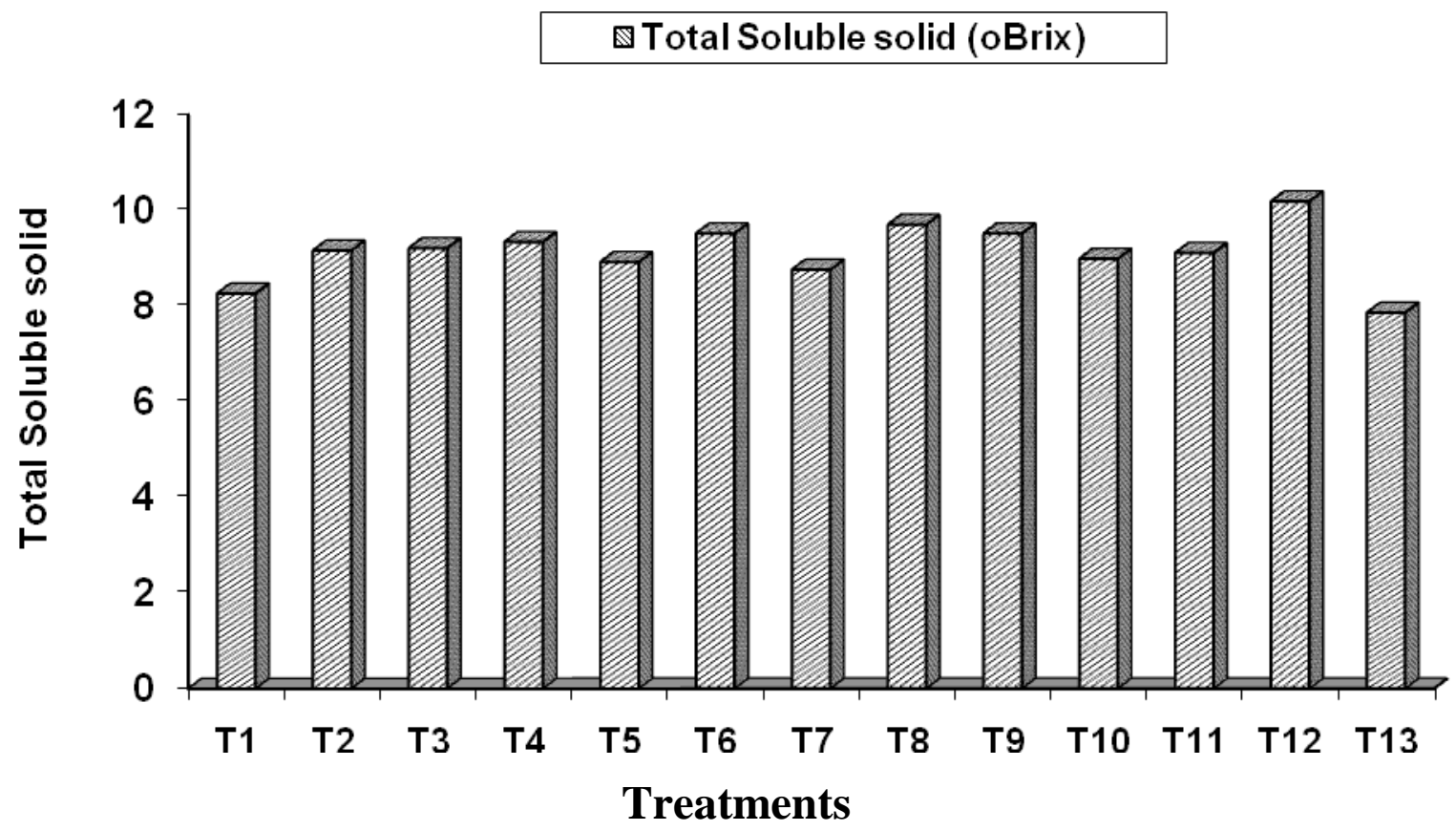

Fig.9 Influence of PGRs and poultry manure on ascorbic acid of fruits (mg/100 g pulp) of Strawberry

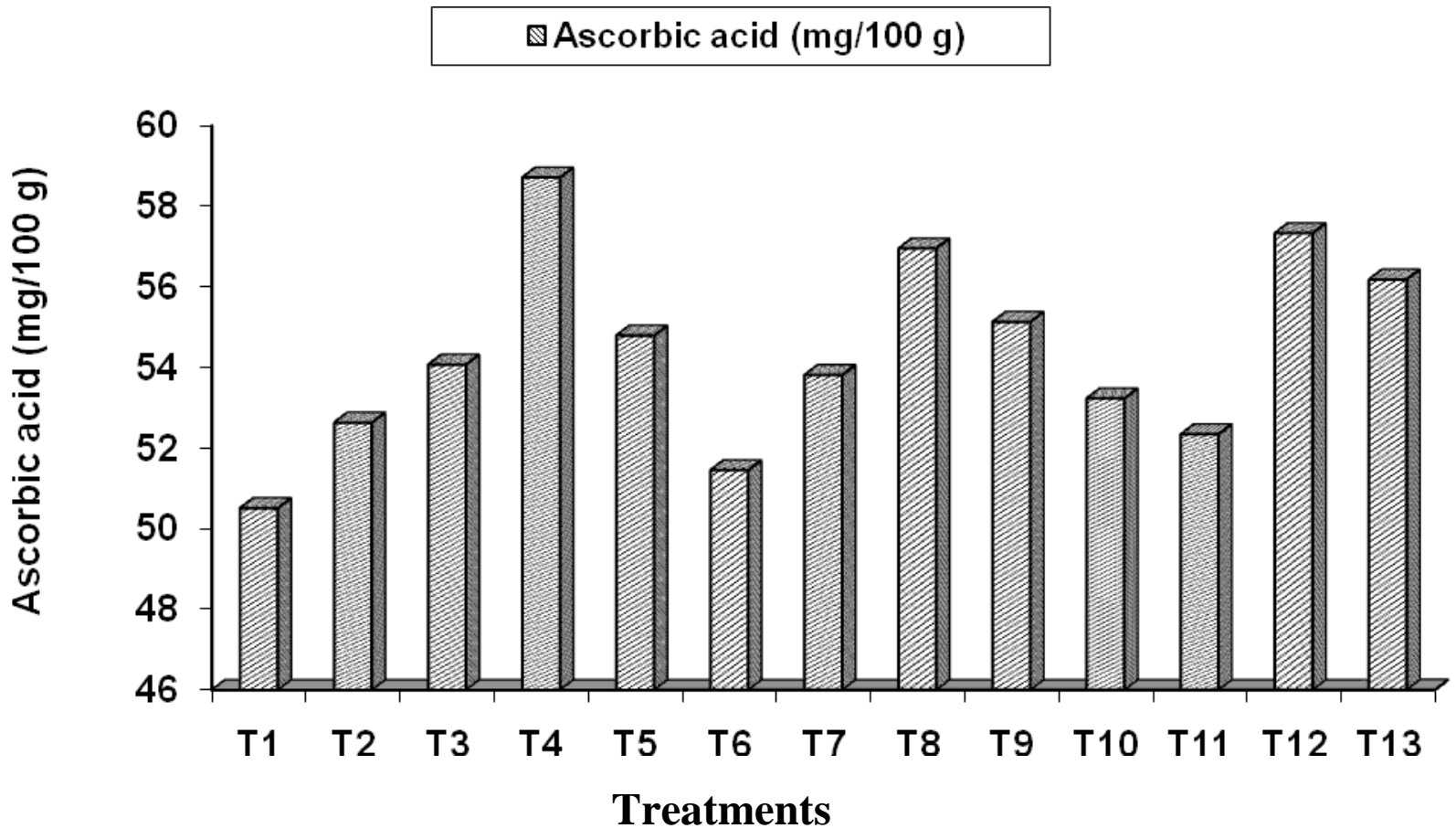


Fig.10 Influence of PGRs and poultry manure on Juice content of fruit (\%) of Strawberry

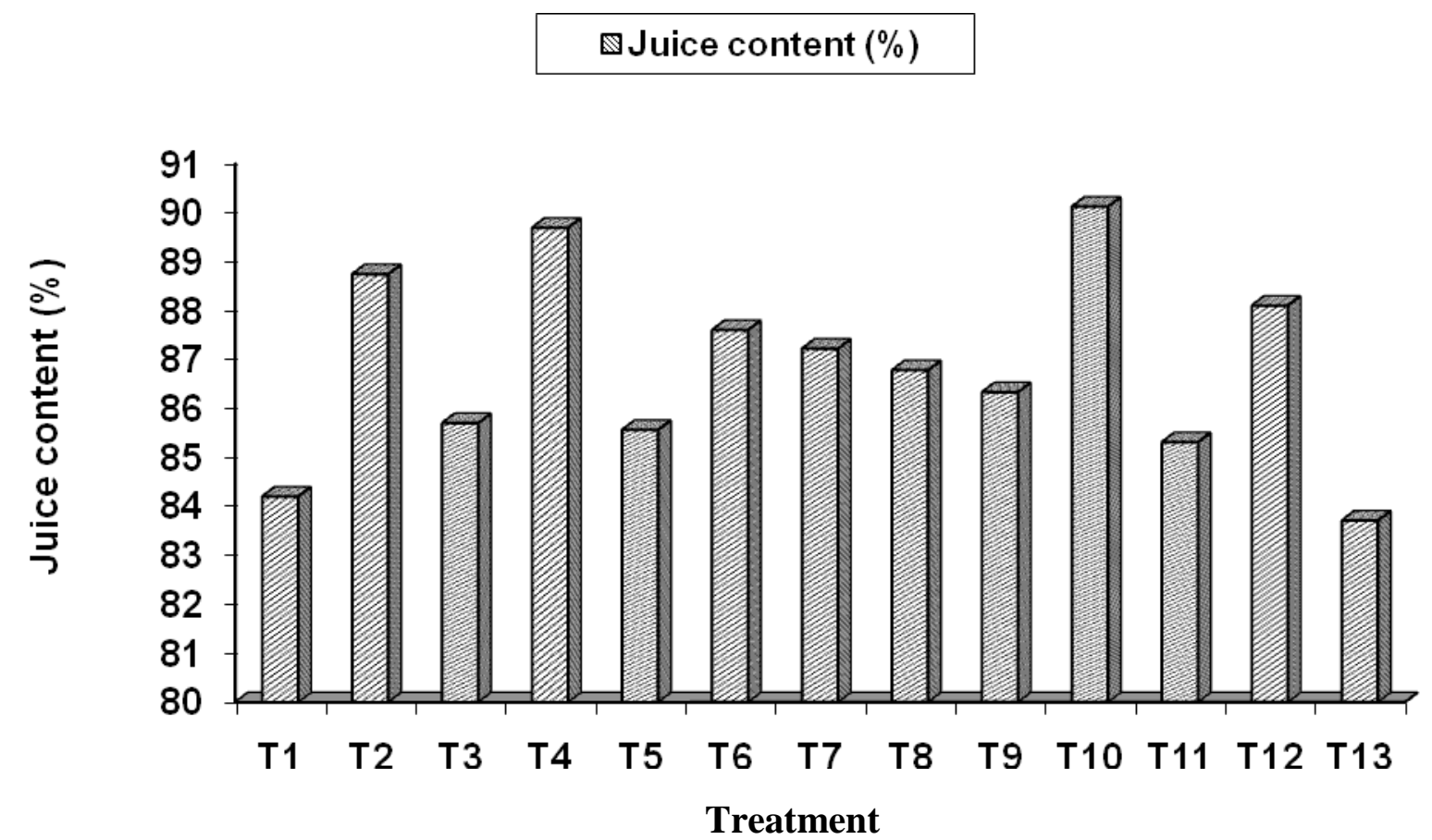

The maximum TSS of fruit (10.19) was noticed with treatment $\mathrm{T}_{12}$ (8.50 tones poultry manure $+1200 \mathrm{ppm}$ CCC) while the minimum TSS of fruit (7.86) was observed with treatment $\mathrm{T}_{13}$ (8.50 tones poultry manure + $200 \mathrm{ppm} \mathrm{GA}_{3}$ ). Similar results were also reported by Kumar et al., (2012) and Kumar et al., (2011).

The present investigation at the Experimental Field of the Department of Horticulture, Allahabad School of Agriculture, Sam Higginbottom Institute of Agriculture, Technology and Sciences (Deemed to-be University), Allahabad U.P. It was concluded that the maximum plant height, plant spread and petiole length, maximum number of leaves per plant was recorded with poultry manure and $\mathrm{GA}_{3}$ treated plants. The highest fruit yield per plant, specific gravity, length diameter ratio was recorded poultry manure and triacontanol treated plants. The highest vitamin $\mathrm{C}$ and TSS was recorded poultry manure and CCC treated plants. The application of poultry manure, $\mathrm{GA}_{3}, \mathrm{CCC}$ and triacontanon is recommended for better physico-chemical parameters. Hence, overall use of plant growth regulators (PGR's) and poultry manure not only increases plant growth and yield but also results in the improvement in fruit quality of strawberry.

\section{References}

Blarke, Z. and Lenz, A. (1983).Effect of triacontanol on dry matter accumulation of quality and production of strawberry. Eruuebsobstbau. 25: 360-361.

Katyayan, A. (2008). Fundament of Agriculture. Kushal Publication and Distribution Varanasi, India, vol. 1: 205.

Kumar, R., Saravanan, S., Bakshi, Parshant and Srivastava, J.N. (2011). Influence of plant growth regulators on growth, 
yield and quality of strawberry (Fragaria $\mathrm{x}$ ananassa Duch.) $c v$. Sweet Charlie. Progressive horticulture. 43 (2): 264- 267.

Kumar,R., Bakshi, M., and Singh, D.B. (2012). Influence of plant growth regulators on growth, yield and quality of strawberrry under U.P. sub tropics.Asian Journal of Horticulture; 7(2): 434-436.

Larson, K.D. (1994). Strawberry in Hand book of environment physiology of fruit crop, Temperate crops. (Eds.) Schaffer, B. and Andersen. P. C., C. R. S. Press Inc. vol. 1, 271-297.

Ngodup, Tsering and Saravanan, S. (2010). Effect of organic fertilizers on plant growth, yield and quality of strawberry (Fragaria $\times$ Ananassa Duch). $c v$. Chandler. M. Sc. Thesis, SHIATS, Allahabad.

Singh, H. and Singh, R. (1979). Effect of $\mathrm{GA}_{3}$ and manuring on fruit quality of strawberry. Punjab Hort. J., 34:207211.

Singh, O. P. and Phogat, K. P. S. (1983). Effect of plant growth regulators on strawberry. Prog. Hort. J., 15: 64-68.
Subhajith, S. S. and Prasad, V. M. (2010). Effect of organic and inorganic fertilizers on growth, Yield and quality of strawberry $c v$. Chandler. M. Sc. thesis, SHIATS, Allahabad.

Tanimoto, E. (1983). GA 3 dependent cell elongation in Lactuca sativa: recovery from growth retardant suppressed elongation with thickening by low concentration of $\mathrm{GA}_{3}$. Plant Cell Physio. 28: 963-973.

Techawongstein, S. (1989). The effect of NAA on fruit quality of strawberry (Fragaria X ananassa Duch.) $c v$. Tioga. Kaen Kaset $=$ Khon Kaen Agriculture Journal, 17(1):30-35.

Thakur, A. S., Jindal, K. K. and Sud, A.(1991). Effect of growth substances on vegetative growth, yield and quality parameters in strawberry $c v$. Teoga. Indian Journal of Horticulture, 48(4):286-290.

Tripathi, V.K. and Shukla, P.K. (2006). Effect of plant bio-regulators on growth, yield and quality of strawberry $c v$. Chandler. Journal of Asian Horticulture; 2(4): 260-263

\section{How to cite this article:}

Sevan Das Khunte, Anil Kumar, Naiem Ansari and Saravanan, S. 2019. Influence of PGRs and Poultry Manure on Physico-Chemical Parameters of Strawberry (Fragaria x ananassa Duch.) cv. Chandler. Int.J.Curr.Microbiol.App.Sci. 8(12): 108-117. doi: https://doi.org/10.20546/ijcmas.2019.812.017 